\title{
First molecular insights into the infection process provoked by Neofusicoccum parvum in Liquidambar styraciflua and the identification of new cysteine-rich proteins in both organisms
}

Rebeca Vázquez-Avendaño

Instituto de Ecología A.C.

José Benjamín Rodríguez-Haas

Instituto de Ecología A.C.

Hugo Velázquez-Delgado

Instituto de Ecología A.C.

Greta Hanako Rosas-Saito

Instituto de Ecología A.C.

Eric Edmundo Hernández-Domínguez

CONACYT/Instituto de Ecología A.C.

Diana Sánchez-Rangel ( $\nabla$ diana.sanchez@inecol.mx )

CONACYT/Instituto de Ecología A.C. https://orcid.org/0000-0002-3206-0900

Research article

Keywords: Neofusicoccum, Liquidambar, defense, cysteine-rich proteins, CFEM domain-containing protein.

Posted Date: June 3rd, 2020

DOl: https://doi.org/10.21203/rs.3.rs-26140/v2

License: (c) (i) This work is licensed under a Creative Commons Attribution 4.0 International License. Read Full License 


\section{Abstract}

Background: Neofusicoccum parvum belongs to the Botryosphaeriaceae family, which groups endophytic and latent pathogens of woody plants responsible for diseases such as cankers, dieback and blight. It is a widespread pathogen with a broad host range, including agricultural, horticultural and forestry plants; therefore, it is relevant to characterize the molecular mechanisms involved in the disease caused by this pathogen. This work reports for the first time $N$. parvum as a pathogen of Liquidambar styraciflua. We established an in vitro pathosystem using foliar tissue to characterize the infection process through scanning electron microscopy (SEM). Because cysteine-rich proteins (CysRPs) have been studied for their important functions in plant-pathogen interactions, new CysRPs were identified for these organisms, and mRNA expression of these proteins was analyzed at early time points during the interaction.

Results: After the first 24 hours post infection, the pathogen caused visible symptoms, and microscopic analysis at 16 days post infection revealed the presence of $N$. parvum pycnidia embedded in $L$. styraciflua leaf tissue. For both organisms, two databases with transcriptomic and genomic information were analyzed, and five new CysRPs were identified for each organism. The length varied between 95 and 204 amino acids, and in silico analysis revealed that all the proteins are potentially secreted. The search for conserved domains and phylogenetic analyses revealed that all the proteins are novel, including two of $N$. parvum that present the well-known CFEM domain. RT-qPCR analysis was conducted at 24 and 72 hours post infection, and the results showed changes in the levels of CysRP mRNAs for both the plant and the fungus at early stages during the interaction.

Conclusions: N. parvum was identified for the first time as a pathogen of L. styraciflua, and this work presents an approach to comprehensively understand the molecular mechanisms involved in this interaction, highlighting the potential involvement of CysRPs of both organisms under this biotic stress.

\section{Background}

A current challenge in the area of plant-pathogen interactions is to comprehensively understand both the molecular mechanisms involved in the defense response of plants against a specific pathogen as well as the mechanisms that the causal agent uses to establish the disease. Therefore, better prevention and diagnostic strategies should be designed to improve disease management.

Fungi are important causal agents of plant diseases, and among fungi, the Botryosphaeriaceae family groups different species that are recognized as endophytic and latent pathogens of trees and other woody plants that are responsible for causing cankers, dieback and even blight in all trees [1]. Neofusicoccum parvum belongs to the Botryosphaeria genus and has been recognized as a widespread pathogen worldwide [2], causing damage to a wide range of hosts, including agricultural, horticultural and forestry plants. Among the hosts of economic relevance are grapevine (Vitis vinifera) [3], avocado (Persea americana Mill.) [4-6], blueberry (Vaccinium spp.) [7] pomegranate (Punica granatum) [8], peach (Prunus persica) [9] and walnut (Juglans regia) [10]. The forestry host plants include the coast redwood (Sequoia 
sempervirens) [11], Norfolk Island pine (Araucaria heterophylla) [12], Eucalyptus globulus [13, 14], and Ginkgo biloba [15]. It is worth mentioning that most studies have focused basically on the isolation of the fungus from symptomatic or asymptomatic tissue, followed by molecular identification and pathogenicity testing through Koch's postulates; however, molecular information has been obtained only for the interaction between grapevine and N. parvum [16-19].

The aggressive nature of $N$. parvum as a phytopathogen suggests the capacity of the fungus to secrete cell wall-degrading enzymes and phytotoxins. The draft genome of the UCR-NP2 N. parvum isolate revealed the presence of glycoside hydrolases, polysaccharide lyases, cutinases, lignin peroxidases and cytochrome P450 monooxygenases that might be involved in lignin degradation [20]. Regarding chemical compounds, it is already known that $N$. parvum is able to produce a variety of phytotoxic compounds that belong to the chemical families of dihydrotoluquinone, epoxylactone, dihydroisocoumarin and hydroxybenzoic acid, such as (-)-terremutin, (R)-mellein and 6-methyl-salicylic acid [21]. Recently, exogenous application of (R)-mellein and (-)-terremutin in $V$. vinifera resulted in upregulation of the salicylic acid (SA)-responsive genes PR1 and GST1. In contrast, the expression of jasmonic acid (JA)/ethylene (ET)-responsive genes remained weak or was even downregulated by (-) terremutin [22].

Until now, there have been no effective control strategies against $N$. parvum, and it has been inferred that horizontal transmission of this pathogen [23] leads to increased risk in a large number of hosts; therefore, it is relevant to characterize the molecular mechanisms involved in disease establishment in other important hosts, for example, Liquidambar styraciflua, a deciduous timber tree that is often used for reforestation, agroforestry, and landscaping [24]. L. styraciflua L. (Atingiaceae) is native to the Americas and is currently distributed in regions localized in North and Central America [25]; it has also been widely introduced in eastern and central China [26]. This tree is also called American sweetgum and is an attractive hardwood species for potential bioenergy production [27]. This work reports for the first time that $N$. parvum is a pathogen of $L$. styraciflua and, through molecular approaches, provides insights into this interaction. The objectives of this work were 1) to describe for the first time that N. parvum is a pathogen of $L$. stytracifula, 2) to establish a reproducible in vitro pathosystem, 3) to characterize the infection process by scanning electron microscopy (SEM) and 4) to identify cysteine-rich proteins (CysRPs) of both organisms that may be important during the defense response and infection process. Recent evidence indicates that pathogen effector proteins are small secreted CysRPs with an N-terminal signal peptide sequence and contain $\leq 300$ amino acids and $\geq 2 \%$ cysteine content $[28,29]$. Some examples of CysRPs are SCR96 of Phtytophtora cactorum [30] and SsSSVP1 in Sclerotinia sclerotiorum [31], the silencing of which reduces pathogen virulence. However, evidence also indicates that effector proteins are highly specific and inherent to each pathogen, and no information has been generated about the CysRPs in any species of the Botryosphaeriaceae family. In addition, CysRPs in plants are important components of the plant innate immune system; some examples include a-defensins, lipid transfer proteins (LTPS), thionins, hevein- and knottin-type peptides and cyclopeptide alkaloids [32].

In this work, a novel pathosystem was identified, and a first attempt was made to examine the role of CysRPs of both actors in the interaction. 


\section{Results}

\section{Identification of $\boldsymbol{N}$. parvum as a pathogen of $L$. styraciflua}

Eleven fungi were isolated from $L$. styraciflua leaves with visible symptoms such as necrosis and discoloration. The potential pathogenicity of the fungi was tested in L. styraciflua leaves and in seedlings of the plant model Arabidopsis thaliana (Fig. 1 and Additional file 1: Fig. S1). The pathogenicity screening identified the fungal Liqui 1-3 strain as the most pathogenic, since in $A$. thaliana seedlings, the fungus covered all the plant tissues, provoking severe leaf discoloration at 7 days post inoculation (dpi). $L$. styraciflua leaves developed clear necrosis and discoloration, including at the principal veins and the petiole, at 8 dpi. Liqui 1-02, Liqui 2-2 and Liqui 2-3 triggered clear disease symptoms in L. styraciflua, but in contrast with the effect produced by Liqui 1-3, no noticeable change was observed in petiole coloration. In $A$. thaliana seedlings, these three isolates did not have a critical pathogenic effect; for example, while Liqui $2-2$ covered more than $50 \%$ of the seedlings, the foliar tissue of the infected plants showed greater vigor than that of the control. Liqui 1-2-01, Liqui 1-2-03 and Liqui 3-2 at 7 dpi showed a discrete pathogenic effect. $A$. thaliana developed a shorter primary root but an increased number of secondary roots during the interaction with these isolates. The isolates Liqui 1-04, Liqui 1-01, Liqui 3-3 and Liqui 3-1 had no effect in $L$. styraciflua leaves or $A$. thaliana seedlings.

To identify the Liqui 1-3 strain at the molecular level, universal and specific primers were used (Additional file 2: Fig. S2 and Additional file 3: Table S1). The analysis revealed that Liqui 1-3 belongs to the Botryosphaeriaceae family as a member of the species N. parvum.

\section{Establishment of the L. styraciflua-N. parvum pathosystem}

Because we were interested in studying the interaction between L. styraciflua and N. parvum, we established a pathosystem using $L$. styraciflua leaves. We noticed that the infection progressed rapidly, since at 1 and $3 \mathrm{dpi}$, the inoculated leaves displayed brownish discoloration that was accentuated over time (Fig. 2), and there was distinct petiole necrosis at 8 and $16 \mathrm{dpi}$; the presence of a whitish mycelium in the necrotic leaf area was also evident. To characterize the infection process in more detail, we analyzed the infected and uninfected tissue using SEM (Fig. 3). SEM images revealed that the fungus grew robustly on the leaf (adaxial) surface, forming a hyphal mass and causing tissue degradation; the cuticle and wax integrity were compromised (Fig. 3a-d). In addition, the infection provoked petiole degradation. A transverse cut of the leaf base showed that the fungus was able to develop pycnidia, an asexual reproductive structure. The pycnidia appeared individually or as aggregates embedded in the plant tissue with thick walls composed of numerous cells (Fig. 3i-I). A longitudinal section of pycnidium showed mature conidia. The conidiogenic cells without septa and with an oval shape were localized perpendicular to the walls of the pycnidium. Because the Botryosphaeriaceae family members are characterized as woody-plant pathogens, we tested the pathogenicity of the Liqui 1-3 strain in fresh stems of L. styraciflua. As shown, N. parvum at 7 dpi triggered distinct symptoms of disease, such as discoloration and necrosis, that covered a zone beyond the site of inoculation (Additional file 4: Fig. S3). 
Detection of hydrogen peroxide in L. styraciflua leaves at early stages of the infection process

Reactive oxygen species (ROS) accumulate in plant cells during pathogen infection and may cause oxidative damage to proteins, DNA, and lipids or act as signaling molecules to regulate the defense response [33,34]. One such species is hydrogen peroxide, and by diaminobenzidine (DAB) staining, we clearly detected the presence of a dark brown precipitate in the infected leaves at early time points ( 1 and $3 \mathrm{dpi}$ ), indicating the presence of $\mathrm{H}_{2} \mathrm{O}_{2}$ (Additional file 5: Fig. S4).

\section{Identification of CysRPs in L. styraciflua and N. parvum and their general features}

CysRPs have been widely studied for their important functions in plant-pathogen interactions, and to identify CysRPs in L. styraciflua and N. parvum, two databases with transcriptomic and genomic information were analyzed (see Materials and Methods). For each organism, five sequences encoding CysRPs were identified (LsCysRP1-5 and NpCysRP1-5), all of which contained a putative start and stop codon with the exception of the LsCysRP3 sequence, in which a stop codon was not present (Table 1 and Additional file 6: Table S2). The amino acid sequence length varied between 95 and 204, and the molecular weight ranged between 7.7 and $17.5 \mathrm{kDa}$. In addition, the cysteine content was determined. Interestingly, with the exception of LsCysRP1, which had a calculated isoelectric point ( $\mathrm{pl}$ ) of 6.04 , the calculated pl values of all the LsCysRPs were greater than 8.67, while, with the exception of NpCysRP1, which had a pl of 7.57, the calculated pl values of all the NpCysRPs were less than 5.48 (Table 1). To predict SS bonds in L. styraciflua and N. parvum CysRPs, the servers Cyscon, Disulfind, DiANNA, CYS_REC and SCRATCH were used. The results revealed that LsCysRP1, LsCysRP2, LsCysRP3, LsCysRP4, and LsCysRP5 have the potential to form 3, 4, 4, 0, and 6 disulfide bonds, respectively. Meanwhile, in N. parvum, 6, 4, 4, 5 and 4 disulfide bridges were estimated for NpCysRP1, NpCysRP2, NpCysRP3, and NpCysRP4 NpCysRP5, respectively. A clear discrepancy regarding the identification of the cysteines that form the pairs was detected among the methods (Additional file 7: Table S3).

To determine whether the CysRPs have the potential to be secreted, an analysis with the TargerP-2.0 server was conducted. All sequences with the exception of the LysCysRP2 sequence have a peptide signal between 17 and 27 amino acids in length. To corroborate these results, additional analyses were performed using the Protter and DeepLoc-1.0 servers, and the results indicated that all the CysRPs have a signal peptide and are extracellular proteins (Table 2).

To identify possible functions and regions of similarity in CysRPs, BLAST and MOTIF tools were used. No significant similarity was found for LsCysRP1, 2 and 4 or for NpCysRP1, 2 and 3. In contrast, LsCysRP3 showed similarity with an LTP and LSCysRP5 with a gibberellin-regulated protein 1-like protein. Interestingly, for both NpCysRP4 and 5, a CFEM domain was identified (Table 1, Fig. 6S).

\section{CysRP phylogenetic analyses}

To obtain more information about NpCysRPs, a corresponding phylogenetic analysis for each of these proteins was conducted (Fig. 4 and 5). Clearly, all the NpCysRPs were grouped in the Botryopshaeria 
lineage, including Lasiodiplodia, Diplodia and Macrophomina species; however, the species in the subclade were not always the same. NpCysRP1, 2 and 5 were closely related to Lasiodiplodia theobromae, while NpCysRP3 and 4 shared a branch with Macrophomina phaseolina.

The NpCysRP1 phylogeny revealed the existence of few orthologous sequences for this protein in databases, and this protein occurred in the Botryosphaeriaceae family only in the species $L$. theobromae (85.00\% identity), Diplodia corticola (85.42\% identity) and Diplodia seriata (82.29\%, identity), as well as in the family Cordycipitaeceae, order Hypocreales, characterized by entomopathogenic fungal species such as Beauveria bassiana and Cordyceps confragosa but with low identities $(29.67 \%$ and $31.36 \%$, respectively); however, the cysteines remained at the same site in the sequences (Additional file 8: Fig. S5). Other species were included in the alignment, such as Aspergillus leporis and Rhizoctonia solani, however, these sequences have a lower number of cysteines and share lower identity.

In addition to the Botryosphaeria lineage, the NpCysRP2 phylogenetic tree contained orthologs of the family Hypocreaceae, order Hypocreales, including seven different species of the Trichoderma genus with identities that ranged from 33.04 to $38.18 \%$. Additionally, members of the family Glomerellaceae were included, such as species of the well-known phytopathogenic genus Colletotrichum, such as the species Colletotrichum asianum, Colletotrichum nymphaeae and Colletotrichum orchidophillum, with 33.04, 36.28 and $37.19 \%$ amino acid identity, respectively. Interestingly, the tree also showed a species of the order Sordariales, the human pathogen Madurella mycetomatis, with $33.90 \%$ identity. The alignment revealed that NpCysRP2 introduces a new cysteine-rich domain with the consensus motif $C^{1}[\mathrm{Y} / \mathrm{F}] \mathrm{PP} \mathrm{x}_{9-10} \mathrm{C}^{2} \mathrm{x}_{6}$ ${ }_{8} \mathrm{C}^{3} \mathrm{C}^{4} \mathrm{x}_{4} \mathrm{C}^{5} \mathrm{x}_{2} \mathrm{Nx}_{2} \mathrm{C}^{6} \mathrm{x}_{10-23} \mathrm{C}^{7} \mathrm{Tx}_{8} \mathrm{C}^{9} \mathrm{x}_{3} \mathrm{C}^{10}$ at the N-terminus. Additionally, the multiple-sequence alignment of NpCysRP2 with the ortholog sequences of $L$. theobromae (67.52\% identity) and D. corticola $(62.07 \%$ identity) showed that NpCysRP2 is a larger protein since the $L$. theobromae and $D$. corticola sequences contain 310 and 296 amino acids, respectively (Additional file 8: Fig. S5). Interestingly, the proteoforms of $L$. theobromae and $D$. corticola presented a transmembrane domain crossing at the carboxyl-end. Moreover, the predicted proteoforms for all the sequences used in the phylogenetic analysis (26 in total) showed the transmembrane helix (Additional file 9: Fig. S6).

A particular phylogeny was noted in the case of NpCysRP3 (Fig. 4C); this protein did not present a welldefined clade distribution within the Botryosphaeriaceae family, and only the M. phaseolina orthologs (MpCysRPs A, B and C) were found, with 64.46, 29.17 and 30.83\% identity, respectively. Interestingly, the Nactriaceae family was represented in the phylogenetic tree with some members of the unique and fascinating Ambrosia Fusarium clade represented by Fusarium euwallaceae and by Fusarium kuroshium, which has been recognized recently as an emerging fungal pathogen $[35,36]$.

NpCysRP5 has a CFEM domain characterized by eight cysteines with the specific consensus motif $\operatorname{PxC}^{1}[A / G] x_{2} C^{2} x_{8}{ }_{12} C^{3} x_{1-3}[x / T] D x_{2-5} C^{4} x C^{5} x_{9-14} C^{6} x_{3-4} C^{7} x_{15-16} C^{8}$ [37]. Interestingly, NpCysRP4 and its orthologs have a CFEM-like domain with a conserved extra cysteine pair (C58 and C94 in the N. parvum sequence) forming the consensus motif $\mathrm{PxC}^{1}[\mathrm{~A} / \mathrm{G}] \mathrm{x}_{2} \mathrm{C}^{2} \mathrm{x}_{8-12} \mathrm{C}^{3} \mathrm{x}_{1-3}[\mathrm{x} / \mathrm{T}] \mathrm{Dx_{2-5 }} \mathrm{C}^{4} \mathrm{C}^{5} \mathrm{x}_{8-13} \underline{\mathrm{C}^{6}} \mathrm{C}^{7} \mathrm{x}_{3-4} \mathrm{C}^{8} \mathrm{x}_{15-}$ 
${ }_{16} \mathrm{C}^{9} \mathrm{x}_{12-13} \underline{\mathbf{C}}^{10}$. NpCysRP4 and NpCysRP5 are well represented in the clade of the Botryosphaeriaceae family, but NpCysRP4 shares a subclade with M. phaseolina, with $78.07 \%$ identity, while NpCysRP5 showed $83.01 \%$ identity with L. theobromae. Cenococcum geophilum and Glonium stellatum belong to the Gloniaceae family and present orthologs for both NpCysRP4 and NpCysRP5. Interestingly, for NpCysRP4, various orthologs in the Nectriaceae family were identified, including in the order Hyporcreales represented by the well-known phytopathogenic Fusarium species Fusarium verticillioides and Fusarium oxysporum, which were not found in the NpCysRP5 phylogenetic tree using 33 sequences. In the case of

NpCysRP5, a clear clade represented by the order Eurotiales was identified, in which different Penicillium species were grouped, with identities that ranged from 34.3 to $41.78 \%$.

In the case of L. styraciflua CysRPs, no similar sequences were found for LsCysRP1, 2 and 4; therefore, it was not possible to construct the corresponding phylogenetic trees. For LsCysRP3, the BLAST ${ }^{\circledR}$ result revealed a sequence identity of $66.98-64.15 \%$ with various Gossypium species and $63.81 \%$ with Vitis pseudoreticulata. Finally, LsCysRP5 showed 73.83-65.42\% identity with different Quercus species, 74.77\% identity with Castanea mollissima and $67.29 \%$ identity with Durio zibethinus.

\section{Expression of CysRP mRNAs of L. styraciflua and $N$. parvum during early times of the infection process.}

To explore whether transcription of CysRP mRNAs of L. styraciflua and N. parvum was modulated at early stages of the interaction, quantitative polymerase chain reaction (qPCR) tests were performed. Fig. $6 \mathrm{~A}$ shows the expression levels of LsPR1, an ortholog of the Nicotiana tabacum gene encoding pathogenesis-related protein 1 (PR1), a protein involved in the defense response in plants and usually used as a defense marker. The qPCR results showed an increase in LsPR1 mRNA at 1 and $3 \mathrm{dpi}$. The opposite profile was observed for all LsCysRP transcripts, as the expression decreased after $1 \mathrm{dpi}$, and LsCysRP2 presented the lowest level at this time post infection. At $3 \mathrm{dpi}$, LsCysRP2 presented the most significant change, and LsCysRP3 remained unchanged, while LsCysRP1, 4 and 5 presented a mild increase.

Finally, our experimental design allowed us to compare the expression of NpCysRP transcripts between 1 and 3 dpi. Fig. 6B shows that there was an increase in the expression of NpCysRP1, 2 and 5 mRNAs, with NpCysRP5 showing the most significant increase. In contrast, NpCysRP4 showed a significant decrease.

\section{Discussion}

L. styraciflua L. (Atingiaceae) is used for reforestation and landscaping and has been proposed as an attractive hardwood species for potential bioenergy production [27]. Because of its importance, it is relevant to determine the factors that limit the integrity of this tree, i.e., the phytosanitary problems. In general, it is assumed that $L$. styraciflua is associated with some pathogens $[27,38]$ In this context, information collected by Hepting in 1971 [39] listed Cercospora liquidambaris, Septoria liquidambaris, Exosporium liquidambaris, Leptothyriella liquidambaris and Gloesporium nervisequm as common foliar pathogens of sweetgum. On the other hand, L. theobromae and Botryosphaeria dothidea have been 
identified as being responsible for provoking stem cankers and dieback in seedlings ubicated in nurseries and outplantings in the USA [38,39]. Currently, there is no new information about the nature of the pathogenic fungi infecting L. styraciflua, but there is a prevalence of the incidence of symptoms associated with diseases. Here, we report that $N$. parvum is associated with foliar damage in $L$. styraciflua, and the pathosystem established in this work identified Liqui 1-3 as a very aggressive strain since it provokes several symptoms at early stages post infection (Fig. 1 and 2). SEM analysis showed that the fungus was able to grow and develop pycnidium to produce a large amount of mature spores, increasing its infective potential (Fig. 3). Our results are consistent with those reported for other Botryosphaeria species. Amponsah and colleagues [40] reported that during the interaction of grapevine and $\mathrm{N}$. luteum, conidial germination occurred at a faster rate ( $3 \mathrm{~h}$ after inoculation) on detached and wounded leaf and shoot surfaces than on attached and nonwounded leaf surfaces, indicating that conidium adhesion, germination and development were affected by the condition of the host plants. Additionally, in mamey sapote stem cuttings infected with L. theobromae at $30 \mathrm{dpi}$, it was possible to identify fruiting bodies embedded in the tissue [41]. It will be interesting in future studies to characterize the Liqui 1-3 strain in greater detail with respect to its capacity to produce lytic enzymes and secondary metabolites with phytotoxic effects in comparison with other strains isolated from other ecological niches. Finally, attention should also be given to other fungi isolated from L. styraciflua that also have pathogenic potential, such as Liqui 1-02 and Liqui 2-2 (Fig. 1 and Additional file 1: Fig. S1).

In addition to the phenotypic effects associated with pathogenicity caused by N. parvum in L. styraciflua, the identification of CysRPs was considered a part of the molecular events triggered by both organisms during infection and the defense response. Five CysRPs were identified for each organism (Table 1), and bioinformatic analyses revealed that LsCysRP1, 2 and 4 are proteins with unknown functions, suggesting that they are species-specific proteins. LsCysRP3 was recognized as an LTP. This protein is considered an antifungal protein classified as PR-14 [42] with an as-yet-unknown mode of action, but in vitro conditions have the ability to enhance intermembranal exchange, causing a posteriori fungal cell death [32]. In barley leaves, LsCysRP3 inhibits the growth of Fusarium solani [43], while transgenic Populus tomentosa overexpressing an LTP of Leonurus japonicus is resistant to Alternaria alternata and Colletotrichum gloesporioides [44]. LsCysRP5 was identified as a gibberellin-regulated protein 1-like protein; these proteins are named the GASA family in A. thaliana and Snakins in Solanum tuberosum. This class of proteins forms 5 or 6 disulfide bonds that are necessary for the structure as a consequence of protein function [45]; moreover, the overexpression of Snakin protein 1 in potato enhances resistance to relevant pathogens [46]. Additionally, Snakin-2 of French bean may form a $42 \mathrm{kDa}$ protein complex with a prolinerich protein and participate in the plant defense process [47]. Thus, in comparison with the reported orthologs of LsCysRP3 and 5, these $L$. styraciflua proteins may have antifungal activity. The expression patterns of the respective mRNAs of LsCysRP3 and 5 during the interaction with $N$. parvum are particularly interesting because of the repressive behavior profile of both mRNAs (Fig. 6). It is well known that many pathogens have evolved tools to evade the host's immune system, so it will be interesting in future studies to investigate this effect further. 
Through genomic and transcriptomic analyses, it has already been recognized that the pathogenic and virulence protein arsenal of $N$. parvum potentially encompasses enzymes that facilitate wood degradation and host colonization $[48,49]$. To the best of our knowledge, our research is the first to identify new CysRPs with potential roles in pathogenesis. After examining the genomic information of $N$. parvum, five sequences were selected with high cysteine content, and the analysis identified NpCysRP5 as a CFEM domain protein, distinguishable from other cysteine-rich domains and inherent to fungi [37]. Although this class of motifs is well represented in the Ascomycota phylum, pioneering research on the CFEM domain $[37,50]$ did not include members of the Botryosphaeriaceae family. In this sense, NpCysRP5 was identified for the first time as an orthodox CFEM protein of $N$. parvum that is expressed early during the infection process in Liquidambar. Interestingly, NpCysRP4 (a protein that apparently lacks a transmembrane domain) has a CFEM-like domain with two additional well-conserved cysteines (Additional file 10: Fig. S7). The presence of these cysteines in NpCysRP4 could cause a disulfide rearrangement and increase conformational stability $[51,52]$ and may increase the possibility of the formation of additional proteoforms with complementary functions contributing to virulence. In accordance with the report by Zhang and collaborators, a positive correlation between CFEM domain occurrence and fungal pathogenicity was shown [37], and it seems that the occurrence of CFEM domain proteins is independent of the lifestyle of the pathogen (i.e., biotrophic, hemibiotrophic or necrotrophic). For example, in Botrytis cinerea (a necrotrophic fungus), BcCFEM1 is highly expressed at early stages of infection in Phaseolus vulgaris, and gene disruption results in decreased virulence [53]. For Magnaporthe grisea, a hemibiotrophic filamentous ascomycete, the mutant pth11 (mutated in a CFEM transmembrane protein) is impaired in appressorium maturation, which has an effect on infection capacity [54]. However, it is important to note that not all CFEM proteins have a role in pathogenicity; for example, three CFEM motif GPI-anchored proteins from Aspergillus fumigatus participate in cell wall stability but not in fungal virulence [55]. Here, we identified a CFEM motif-containing protein of N. parvum (NpCysRP5) that also contains a putative transmembrane helix and is expressed during the early infection stages in $L$. styraciflua. It will be exciting to further elucidate the exact contribution of this protein to pathogenesis. Finally, the phylogenetic analyses identified orthologs of NpCysRP4 and NpCysRP5 in additional Botryosphaeriaceae species, contributing to the knowledge regarding this important pathogen of woody plants (Fig. 5). Additionally, the expression analysis indicated contrasting mRNA expression profiles for NpCysRP4 versus NpCysRP5 (Fig. 6), and because only NpCysRP5 mRNA expression showed a positive correlation during early stages of infection, we believe that NpCysRP5 is a better candidate with a significant role during pathogenesis, emphasizing the fact that NpCysRP4, with a CFEM-like domain, has another important function that may be discovered in future work.

In addition to the new CFEM-like motif, NpCysRP2 also introduces a new cysteine-rich domain with the following characteristics: 1) the consensus motif deduced is $C^{1}[Y / F] \times P x_{9-10} C^{2} x_{6-8} C^{3} C^{4} x_{4} C^{5} x_{2} N{ }_{2} C^{6} x_{10}$ ${ }_{23} \mathrm{C}^{7} \mathrm{Tx}_{8} \mathrm{C}^{9} \mathrm{x}_{3} \mathrm{C}^{10}$,2) all cysteines are conserved, and 3) a transmembrane helix toward the carboxyl terminus is also conserved. These characteristics strongly suggest the existence of a new group of proteins, and because augmented expression was observed at early time points, NpCysRP2 is also a 
good candidate with a role during pathogenesis. All these data indicated that NpCysRP2 is a new protein, which we named fungal cysteine-rich transmembrane protein (FCRTP).

Finally, phylogenetic analyses indicated two important points: 1) NpCysRPs are present in various fungal families, and 2) each NpCysRP is associated with a particular species. For example, for NpCysRP4, the order Eurotiales is well represented by several Penicillium species, while for NpCysRP5, the order Hypocrales is represented by members of the Fusarium genus, indicating that N. parvum is a very versatile fungus.

\section{Conclusions}

In this study, we showed that N. parvum is an aggressive pathogen of L. styraciflua. In addition, we identified novel CysRPs of both organisms, such as NpCysRP2, which seems to be conserved through various fungi and contains a novel cysteine-rich motif and a putative transmembrane domain. Additionally, NpCysRP4 was identified as a novel CFEM-like domain. In the case of LsCysRPs, three of the proteins did not present a predicted putative function. Analysis of the expression during the plantpathogen interaction revealed that all the LsCysRPs presented a repressive expression profile in comparison with the expression profile of NpCysRPs, suggesting the involvement of an interesting molecular mechanism during this interaction. Finally, all the CysRPs identified in this work are suitable candidates for further investigations to increase the knowledge regarding the molecular events that occur during the defense response of woody species against $N$. parvum.

\section{Methods}

\section{Plant material}

L. styraciflua leaves with disease symptoms such as chlorosis and necrosis were sampled from five different points of trees located within the cloud forest Santuario del Bosque Niebla (SBN) at Xalapa, Veracruz, Mexico $\left(19^{\circ} 30^{\prime} 37^{\prime \prime} \mathrm{N} 96^{\circ} 56^{\prime} 34^{\prime \prime} \mathrm{W}\right)$. This forest is a protected area belonging to the Institute of Ecology (INECOL A.C.) and is used to collect samples for research purposes. The identification of Liquidambar specimens was performed by the curators Carlos Duran and Sergio Avendaño in the Herbarium-XAL of INECOL A.C. The leaves and stems used for artificial inoculation were also collected from healthy trees in SBN.

\section{Fungi isolation from L. styraciflua leaves}

The complete leaves were cut with gardening scissors, deposited in Ziploc bags and kept at $4^{\circ} \mathrm{C}$. The leaves were cut into small pieces of $0.5 \mathrm{~cm} \times 0.5 \mathrm{~cm}$ and were disinfected with ethanol (96\%) and chlorine solution (20\%) for 2 min each and rinsed five times with sterile water. For fungal isolation, the disinfected tissue was placed in Petri dishes containing potato dextrose agar (PDA) and incubated for 2-4 days at $25^{\circ} \mathrm{C}$ or $29^{\circ} \mathrm{C}$ under two different light conditions: darkness or a $12 \mathrm{~h} \mathrm{light/} 12 \mathrm{~h}$ dark cycle. 
Monosporic cultures were grown for all the isolated fungi that showed different morphologies. The isolates were preserved in $10 \%$ glycerol at $-80^{\circ} \mathrm{C}$.

\section{DNA extraction and molecular identification of the Liqui 1-3 isolate by PCR}

Each isolate was grown on PDA in 10-cm-diameter Petri dishes for $9-10$ days at $28^{\circ} \mathrm{C}$ in darkness. The mycelium was collected with a scalpel and pulverized to isolate genomic DNA according to the protocol described by Tapia-Tussell et al. [56] with minor modifications. Specifically, in the lysis step, we added 1 $\mathrm{mL}$ of SDS buffer, and the purification step was replaced with the addition of $500 \mu \mathrm{L}$ of phenol:chloroform:isoamyl alcohol (Sigma-Aldrich, USA). For molecular identification of the Liqui 1-3 isolate, we used previously published primers that amplify regions of the b-tubulin gene [57]; the internal transcribed spacer (ITS) regions [58]; a portion of the RNA polymerase II subunit (RPB2) [59]; the BotF15 locus, an unknown locus containing microsatellite repeats [60]; and the portion of the gene encoding translation elongation factor 1 alpha (EF-1a) [59] (see supplementary Table 1S). Genes from these five regions were amplified from genomic DNA using PCR with Platinum ${ }^{\circledR}$ Taq DNA Polymerase, High Fidelity (InvitrogenÔ, Thermo Fisher Scientific, USA). Each PCR was carried out in a $50 \mu \mathrm{L}$ reaction containing 20$100 \mathrm{ng}$ of template DNA, $1 \times$ High-Fidelity PCR Buffer, $100 \mu \mathrm{M}$ each dNTP $(0.2 \mathrm{mM}), 2.0 \mathrm{mM}$ MgSO4, $1 \mu \mathrm{L}$ of each forward and reverse primer $(20 \mu \mathrm{M})$, and $1 \mathrm{U} / \mathrm{rxn}$ Platinum ${ }^{\circledR}$ Taq DNA Polymerase, High Fidelity (InvitrogenÔ, Thermo Fisher Scientific, USA). The optimal PCR conditions on a SureCycler 8800 (Agilent Technologies, Inc., USA) were as follows: initial denaturation at $94^{\circ} \mathrm{C}$ for $1 \mathrm{~min}$, followed by 32 cycles of $94^{\circ} \mathrm{C}$ for $15 \mathrm{~s}, 58^{\circ} \mathrm{C}$ (b-tubulin, RPB2 and Botf 15$) / 55^{\circ} \mathrm{C}$ (ITS and EF- $1 \mathrm{a}$ ) for $30 \mathrm{~s}$, and $72^{\circ} \mathrm{C}$ for $1 \mathrm{~min}$ and a final extension step of $72^{\circ} \mathrm{C}$ for $5 \mathrm{~min}$.

The sizes and concentration of the amplicons were visually checked by electrophoresis on a $1 \%$ agarose gel, and PCR products were purified using the Wizard SV Gel and PCR Clean-up System (Promega,USA). The DNA concentration was measured on a NanoDrop 2000c spectrophotometer (Thermo Fisher Scientific, USA). Samples were sent to Langebio, Cinvestav, for sequencing. DNA sequences were analyzed using the nucleotide collection (nr/nt) optimized for highly similar sequences (MegaBLAST) in NCBI (https://blast.ncbi.nlm.nih.gov/Blast.cgi).

\section{Pathogenicity assay in $A$. thaliana seedlings}

Seeds of $A$. thaliana ecotype Col-0 were surface-disinfected with $96 \%(\mathrm{v} / \mathrm{v})$ ethanol for 7 min and $20 \%$ $(\mathrm{v} / \mathrm{v})$ bleach for $7 \mathrm{~min}$, rinsed five times for $5 \mathrm{~min}$ with distilled water and stratified for 2 days at $4^{\circ} \mathrm{C}$. Seeds were grown on each agar plate (10 seeds per plate) containing $0.2 \times$ Murashige and Skoog medium (MS basal salt mixture, Phytotechnology Laboratories, USA), $0.6 \%$ sucrose (Merck, Germany ) and $1 \%$ Agar Plant TC at pH 7. Plates were incubated at $21 \pm 1^{\circ} \mathrm{C}$ under a 12-h light/12-h dark cycle for 7 days. Then, the seedlings were inoculated with $0.5 \mathrm{~cm} \times 0.5 \mathrm{~cm}$ agar plugs containing the isolate. Then, the plates were incubated for seven additional days under the same conditions, and a photograph was taken with a camera D3200 (Nikon, Japan). All the experiments were carried out in triplicate.

\section{Pathogenicity assay in L. styraciflua leaves and stems}


Healthy L. styraciflua leaves and stems were collected from the cloud forest SBN at Xalapa, Veracruz, Mexico. Once the samples were collected, they were immediately placed in plastic bags that contained sterile water to preserve the moisture content. The leaves were collected and sterilized the same day that the experiment was carried out. The leaves were sterilized with $2 \%$ sodium hypochlorite for $1 \mathrm{~min}$ and then washed five times with sterile distilled water. Three sterilized leaves were placed in a humid chamber. The humid chambers were prepared by placing a circle of sterile filter paper in the bottom of a Petri dish $(150 \times 20 \mathrm{~mm})$ previously sterilized with UV light for $15 \mathrm{~min}$. Approximately $4-5 \mathrm{~mL}$ of sterile distilled water was added to the filter paper. The leaves (3) were mechanically damaged with a sterile scalpel at the base and then inoculated with a plug (approximately $0.5 \times 0.5 \mathrm{~cm}$ ) of $N$. parvum (Liqui 1-3) previously grown on PDA medium. Leaves with damage to the base and leaves with no damage to the base were used as controls. Finally, the control and inoculated leaves were incubated at $25 \pm 2^{\circ} \mathrm{C}$ with $80 \%$ relative humidity in darkness in a plant growth chamber (Thermo Scientific, USA). Photographs were taken at 0, 1, 3, 8 and 18 dpi with a camera D3200 (Nikon, Japan).

Stem infection experiments were carried out as follows: previously sterilized young branches of an adult L. styraciflua tree were cut with a scalpel or a single-edged knife into fragments of approximately $10 \mathrm{~cm}$ and then cut longitudinally. The $L$. styraciflua stems were placed facing upward in quadruplicate inside a humid chamber that was prepared as previously described. The plant stems were infected at the center of the vascular tissue with a plug (approximately $0.5 \times 0.5 \mathrm{~cm}$ ) of $N$. parvum (LSH1-083) previously grown on PDA medium. We included a negative control inoculated with a PDA plug lacking fungus. Finally, the sample was kept in darkness and incubated at $25 \pm 2{ }^{\circ} \mathrm{C}$ with $80 \%$ relative humidity in a plant growth chamber (Thermo Scientific, USA).

\section{DAB staining}

L. styraciflua leaves, infected and uninfected, were stained following a previously reported protocol [61]

\section{SEM}

Sections of L. styraciflua leaves, infected and uninfected, at 1, 3 and 8 dpi were fixed in $2.5 \%$ glutaraldehyde for $12 \mathrm{~h}$ and then washed in $0.1 \mathrm{M}$ Sorensen's phosphate buffer. The samples were dehydrated in an ethanol solution series from 30 to $100 \%$ in ten stages for 40 min each, dried in a critical point drier K850 (Quorum Technologies Ltd, UK), coated with gold in rotary pumped sputter coater Q150RS (Quorum Technologies Ltd, UK) [62], and observed under a scanning electron microscope Quanta $^{\text {TM }}$ FEG 250 (Thermo Fisher Scientific, USA).

\section{CysRP identification}

For identification of CysRPs of L. styraciflua, we used the Hardwood Genomics Project database (https://www.hardwoodgenomics.org/), and for N. parvum, we used the genomic information already published by Blanco et al. (10.1128/genomeA.00339-13). Prediction of subcellular localization for all proteins as well as signal peptide cleavage were performed with the TargetP 1.1 server [63] and Protter 
[64]. The predicted localization was evaluated with SignalP-5.0. [65] and DeepLoc-1.0 [66]. To infer the possible functions of CysRPs, we used BLAST (National Center for Biotechnology Information; https://blast.ncbi.nlm.nih.gov/Blast.cgi), Motif search (GenomeNet; https://www.genome.jp/tools/motif/MOTIF.html) and DeepGOPlus [67] approaches.

\section{Phylogenetic trees}

Phylogenetic analysis was performed with Mega X software [68] using the maximum likelihood method and JTT matrix-based model [69]. Jalview software was used to perform the alignments [70], with the Tcoffee method [71], and finally, the BLAST tool was used to find similar sequences in other fungi.

\section{RNA extraction and gene expression}

Total RNA was extracted using the Plant/Fungi Total RNA Purification Kit (Norgen Biotek Corp., Canada) following the manufacturer's recommendations. The amount of RNA was determined with a NanoDrop ${ }^{\mathrm{TM}}$ 2000c spectrophotometer (Thermo Fisher Scientific, USA), and RNA integrity was evaluated based on the A260 nm/A280 nm ratio and by electrophoresis in a 1.5\% agarose gel. Then, $1 \mu \mathrm{g}$ of the RNA was treated with deoxyribonuclease I from Invitrogen ${ }^{\text {TM }}$ (Thermo Fisher Scientific, USA) following the manufacturer's instructions, after which the RNA was used as a template for synthesis of cDNA with the reverse transcriptase Superscript III Invitrogen ${ }^{\text {TM }}$ following the manufacturer's protocol.

Quantitative real-time PCR (qRT-PCR) was carried out using SYBR ${ }^{\mathrm{TM}}$ Green PCR Master Mix (Thermo Fisher Scientific, USA), and the final reaction volume was $20 \mu \mathrm{L}$, containing $10 \mu \mathrm{L}$ of SYBR ${ }^{\mathrm{TM}}$ Green (Thermo Fisher Scientific, USA), $1.0 \mu \mathrm{L}$ of each primer (10 mM), and $8 \mu \mathrm{L}$ of cDNA (50 $\mathrm{ng}$ or $5.0 \mathrm{ng}$ ). For oligo efficiency determination, curves with 50.0, 5.0, 0.5, 0.05 and $0.005 \mathrm{ng}$ of cDNA were generated. Real-time PCR was performed on a Stratagene Mx300P system (Agilent Technologies, USA) under the standard thermal profile design: $10 \mathrm{~min}$ at $95^{\circ} \mathrm{C}$ followed by a total of 40 cycles of $30 \mathrm{~s}$ at $95^{\circ} \mathrm{C}, 1 \mathrm{~min}$ at $55^{\circ} \mathrm{C}$ and $1 \mathrm{~min}$ at $72^{\circ} \mathrm{C}$. Oligo specificity was determined by a melting curve analysis with continuous fluorescence data acquisition during the $95-55^{\circ} \mathrm{C}$ melt. For oligo design, Primer3 software was used following the parameters suggested by Thornton and Basu [72]. Relative expression levels for validated genes were calculated by the (see Formula in the Supplementary Files) method [73], and oligos for Tip41, actin and ubiquitin of L. styraciflua, as reference genes, were evaluated (all primers are listed in Additional file 3: Table S1). The geometric mean between Tip41 and actin was used as a reference [74].

\section{Abbreviations}

CFEM: common in several fungal extracellular membrane proteins; CysRPs: cysteine-rich proteins; DAB: diaminobenzidine; dpi: days post inoculation; ET: ethylene; FCRTP: fungal cystine-rich transmembrane protein; GST1: glutathione S-transferase-1; JA: jasmonic acid; LTP: lipid transfer protein; LsCysRPs: Liquidambar styraciflua cysteine-rich proteins; mRNAs: messenger RNA; NpCysRPs: Neofusicoccum parvum cysteine-rich proteins; PR-1: pathogenesis-related protein 1; ROS: reactive oxygen species; SA: 
salicylic acid; SCR96: small cysteine rich 96; SEM: scanning electron microscopy; SBN: Santuario del Bosque de Niebla; SsSSVP1: small secreted virulence-related protein in Sclerotinia sclerotiorum.

\section{Declarations}

\section{Ethics approval and consent to participate}

Not applicable

\section{Consent for publication}

Not applicable

\section{Availability of data and materials}

Not applicable

\section{Competing interests}

The authors declare that they have no competing interests.

\section{Funding}

The purchase of the supplies and laboratory materials for isolation, fungus identification, pathosystem establishment and SEM analysis was financially supported by the project CONAFOR-CONACYT, 2015C01-265677. The CysRP analysis, data interpretation and writing of the manuscript were financially supported by INECOL A.C. (20047/90001).

\section{Authors' contributions}

EEHD and DSR conceived the idea, designed the experiments and wrote the manuscript. RVA, HVD and JBRH carried out the experiments and data interpretation. GHRS performed the SEM experiments. All authors have read and approved the final manuscript.

\section{Acknowledgments}

We would like to thank Martín Aluja Schuneman Hofer and Andrés Lira Noriega for funding management. Additionally, we thank M.Sc. Alexandro G. Alonso Sánchez for providing technical assistance during RTqPCR experiments.

\section{References}

1. Slippers B, Wingfield MJ. Botryosphaeriaceae as endophytes and latent pathogens of woody plants: diversity, ecology and impact. Fungal Biology Reviews. 2007;21:90-106.

doi:10.1016/j.fbr.2007.06.002. 
2. Sakalidis ML, Slippers B, Wingfield BD, Hardy GEStJ, Burgess TI. The challenge of understanding the origin, pathways and extent of fungal invasions: global populations of the Neofusicoccum parvumN. ribis species complex. Diversity and Distributions. 2013;19:873-83. doi:10.1111/ddi.12030.

3. Lorenzini M, Cappello MS, Zapparoli G. Isolation of Neofusicoccum parvum from withered grapes: strain characterization, pathogenicity and its detrimental effects on passito wine aroma. Journal of Applied Microbiology. 2015;119:1335-44. doi:10.1111/jam.12931.

4. Carrillo JD, Eskalen A, Rooney-Latham S, Scheck HJ. First Report of Neofusicoccum nonquaesitum Causing Branch Canker and Dieback of Avocado in California. Plant Disease. 2016;100:1778-1778. doi:10.1094/PDIS-11-15-1357-PDN.

5. Molina-Gayosso E, Silva-Rojas H v., García-Morales S, Avila-Quezada G. First Report of Black Spots on Avocado Fruit Caused by Neofusicoccum parvum in Mexico. Plant Disease. 2012;96:287-287. doi:10.1094/PDIS-08-11-0699.

6. Valencia AL, Gil PM, Latorre BA, Rosales IM. Characterization and Pathogenicity of Botryosphaeriaceae Species Obtained from Avocado Trees with Branch Canker and Dieback and from Avocado Fruit with Stem End Rot in Chile. Plant Disease. 2019;103:996-1005. doi:10.1094/PDIS-07-18-1131-RE.

7. Espinoza JG, Briceño EX, Chávez ER, Úrbez-Torres JR, Latorre BA. Neofusicoccum spp. Associated with Stem Canker and Dieback of Blueberry in Chile. Plant Disease. 2009;93:1187-94. doi:10.1094/PDIS-93-11-1187.

8. Palavouzis SC, Tzamos S, Paplomatas E, Thomidis T. First report of Neofusicoccum parvum causing shoot blight of pomegranate in Northern Greece. New Disease Reports. 2015;32:10. doi:10.5197/j.2044-0588.2015.032.010.

9. Song ZX, Liao J, Luo H, Zhang F, Sun ZX, Liu QK, et al. First Report of Neofusicoccum parvum Associated with Shoot Blight on Peaches in China. Plant Disease. 2019;::PDIS-12-18-2148. doi:10.1094/PDIS-12-18-2148-PDN.

10. Cheon W, Kim YS, Lee SG, Jeon YH, Chun I-J. First Report of Branch Dieback of Walnut Caused by Neofusicoccum parvum in Korea. Plant Disease. 2013;97:1114-1114. doi:10.1094/PDIS-12-12-1137PDN.

11. Aćimović SG, Rooney-Latham S, Albu S, Grosman DM, Doccola JJ. Characterization and Pathogenicity of Botryosphaeriaceae Fungi Associated with Declining Urban Stands of Coast Redwood in California. Plant Disease. 2018;102:1950-7. doi:10.1094/PDIS-02-18-0339-RE.

12. Golzar H, Burgess TI. Neofusicoccum parvum, a causal agent associated with cankers and decline of Norfolk Island pine in Australia. Australasian Plant Pathology. 2011;40:484-9. doi:10.1007/s13313011-0068-4.

13. Iturritxa E, Slippers B, Mesanza N, Wingfield MJ. First report of Neofusicoccum parvum causing canker and die-back of Eucalyptus in Spain. Australasian Plant Disease Notes. 2011;6:57-9. doi:10.1007/s13314-011-0019-5. 
14. Lopes A. Diversity and phylogeny of Neofusicoccum species occurring in forest and urban environments in Portugal. Mycosphere. 2016;7:906-20. doi:10.5943/mycosphere/si/1b/10.

15. Mirhosseini HA, Babaeizad V, Rahimlou S. Neofusicoccum parvum, agent of leaf spot on the new host Ginkgo biloba in Iran. New Disease Reports. 2014;30:12. doi:10.5197/j.20440588.2014.030.012.

16. Massonnet M, Figueroa-Balderas R, Galarneau ERA, Miki S, Lawrence DP, Sun Q, et al. Neofusicoccum parvum Colonization of the Grapevine Woody Stem Triggers Asynchronous Host Responses at the Site of Infection and in the Leaves. Frontiers in Plant Science. 2017;8. doi:10.3389/fpls.2017.01117.

17. Spagnolo A, Magnin-Robert M, Alayi TD, Cilindre C, Schaeffer-Reiss C, van Dorsselaer A, et al. Differential Responses of Three Grapevine Cultivars to Botryosphaeria Dieback. Phytopathology. 2014;104:1021-35. doi:10.1094/PHYTO-01-14-0007-R.

18. Spagnolo A, Mondello V, Larignon P, Villaume S, Rabenoelina F, Clément C, et al. Defense Responses in Grapevine (cv. Mourvèdre) after Inoculation with the Botryosphaeria Dieback Pathogens Neofusicoccum parvum and Diplodia seriata and Their Relationship with Flowering. International Journal of Molecular Sciences. 2017;18:393. doi:10.3390/ijms18020393.

19. Czemmel S, Galarneau ER, Travadon R, McElrone AJ, Cramer GR, Baumgartner K. Genes Expressed in Grapevine Leaves Reveal Latent Wood Infection by the Fungal Pathogen Neofusicoccum parvum. PLOS ONE. 2015;10:e0121828. doi:10.1371/journal.pone.0121828.

20. Blanco-Ulate B, Rolshausen P, Cantu D. Draft Genome Sequence of Neofusicoccum parvum Isolate UCR-NP2, a Fungal Vascular Pathogen Associated with Grapevine Cankers. Genome Announcements. 2013;1. doi:10.1128/genomeA.00339-13.

21. Abou-Mansour E, Débieux J-L, Ramírez-Suero M, Bénard-Gellon M, Magnin-Robert M, Spagnolo A, et al. Phytotoxic metabolites from Neofusicoccum parvum, a pathogen of Botryosphaeria dieback of grapevine. Phytochemistry. 2015;115:207-15. doi:10.1016/j.phytochem.2015.01.012.

22. Trotel-Aziz P, Abou-Mansour E, Courteaux B, Rabenoelina F, Clément C, Fontaine F, et al. Bacillus subtilis PTA-271 Counteracts Botryosphaeria Dieback in Grapevine, Triggering Immune Responses and Detoxification of Fungal Phytotoxins. Frontiers in Plant Science. 2019;10. doi:10.3389/fpls.2019.00025.

23. Mehl JWM, Slippers B, Roux J, Wingfield MJ. Overlap of latent pathogens in the Botryosphaeriaceae on a native and agricultural host. Fungal Biology. 2017;121:405-19. doi:10.1016/j.funbio.2016.07.015.

24. Pedraza RA, Williams-Linera G. Evaluation of native tree species for the rehabilitation of deforested areas in a Mexican cloud forest. New Forests. 2003;26:83-99. doi:10.1023/A:1024423511760.

25. Adams J, Lingbeck J, Crandall P, Martin E, O’Bryan C. Sweetgum: a new look. iForest Biogeosciences and Forestry. 2015;8:719-27. doi:10.3832/ifor1462-008.

26. Gao L, Li Y, Xu Y, Hulcr J, Cognato Al, Wang J-G, et al. Acanthotomicus sp. (Coleoptera: Curculionidae: Scolytinae), a New Destructive Insect Pest of North American Sweetgum Liquidambar styraciflua in 
China. Journal of Economic Entomology. 2017;110:1592-5. doi:10.1093/jee/tox123.

27. Kline KL, Coleman MD. Woody energy crops in the southeastern United States: Two centuries of practitioner experience区. Biomass and Bioenergy. 2010;34:1655-66.

doi:10.1016/j.biombioe.2010.05.005.

28. Lu S, Edwards MC. Genome-Wide Analysis of Small Secreted Cysteine-Rich Proteins Identifies Candidate Effector Proteins Potentially Involved in Fusarium graminearum -Wheat Interactions. Phytopathology. 2016;106:166-76. doi:10.1094/PHYTO-09-15-0215-R.

29. Io Presti L, Lanver D, Schweizer G, Tanaka S, Liang L, Tollot M, et al. Fungal Effectors and Plant Susceptibility. Annual Review of Plant Biology. 2015;66:513-45. doi:10.1146/annurev-arplant043014-114623.

30. Chen X-R, Li Y-P, Li Q-Y, Xing Y-P, Liu B-B, Tong Y-H, et al. SCR96, a small cysteine-rich secretory protein of $P$ hytophthora cactorum, can trigger cell death in the Solanaceae and is important for pathogenicity and oxidative stress tolerance. Molecular Plant Pathology. 2016;17:577-87. doi:10.1111/mpp.12303.

31. Lyu X, Shen C, Fu Y, Xie J, Jiang D, Li G, et al. A Small Secreted Virulence-Related Protein Is Essential for the Necrotrophic Interactions of Sclerotinia sclerotiorum with Its Host Plants. PLOS Pathogens. 2016;12:e1005435. doi:10.1371/journal.ppat.1005435.

32. de Lucca AJ, Cleveland TE, Wedge DE. Plant-derived antifungal proteins and peptides. Canadian Journal of Microbiology. 2005;51:1001-14. doi:10.1139/w05-063.

33. Segal LM, Wilson RA. Reactive oxygen species metabolism and plant-fungal interactions. Fungal Genetics and Biology. 2018;110:1-9. doi:10.1016/j.fgb.2017.12.003.

34. Lehmann S, Serrano M, L'Haridon F, Tjamos SE, Metraux J-P. Reactive oxygen species and plant resistance to fungal pathogens. Phytochemistry. 2015;112:54-62.

doi:10.1016/j.phytochem.2014.08.027.

35. Freeman S, Sharon M, Maymon M, Mendel Z, Protasov A, Aoki T, et al. Fusarium euwallaceae sp. nov. -a symbiotic fungus of Euwallacea sp., an invasive ambrosia beetle in Israel and California. Mycologia. 2013;105:1595-606. doi:10.3852/13-066.

36. Na F, Carrillo JD, Mayorquin JS, Ndinga-Muniania C, Stajich JE, Stouthamer R, et al. Two Novel Fungal Symbionts Fusarium kuroshium sp. nov. and Graphium kuroshium sp. nov. of Kuroshio Shot Hole Borer ( Euwallacea sp. nr. fornicatus ) Cause Fusarium Dieback on Woody Host Species in California. Plant Disease. 2018;102:1154-64. doi:10.1094/PDIS-07-17-1042-RE.

37. Zhang Z-N, Wu Q-Y, Zhang G-Z, Zhu Y-Y, Murphy RW, Liu Z, et al. Systematic analyses reveal uniqueness and origin of the CFEM domain in fungi. Scientific Reports. 2015;5:13032. doi:10.1038/srep13032.

38. Cram MM, Coyle DR, Spaine P, Lumpkin S v, Coleman MD. Fertilization and Irrigation Effect on Botryosphaeriaceae Canker Development in Intensively Managed Sweetgum ( Liquidambar styraciflua ). 2010. p. 26-34. 
39. Hepting GH. Diseases of forest and shade trees of the United States. 1971;:vii, 658 p. file://catalog.hathitrust.org/Record/001516558.

40. Amponsah NT, Jones EE, Ridgway HJ, Jaspers M v. Microscopy of some interactions between Botryosphaeriaceae species and grapevine tissues. Australasian Plant Pathology. 2012;41:665-73. doi:10.1007/s13313-012-0159-x.

41. Tovar-Pedraza JM, Mora-Aguilera JA, Nava-Díaz C, Téliz-Ortiz D, Valdovinos-Ponce G, Villegas-Monter Á, et al. Identification, pathogenicity, and histopathology of Lasiodiplodia theobromae on mamey sapote grafts in Guerrero, México. Agrociencia. 2012;46:147-61. http://www.scielo.org.mx/scielo.php?script=sci_arttext\&pid=S1405-31952012000200005\&nrm=iso.

42. van Loon LC, van Strien EA. The families of pathogenesis-related proteins, their activities, and comparative analysis of PR-1 type proteins. Physiological and Molecular Plant Pathology. 1999;55:85-97. doi:10.1006/pmpp.1999.0213.

43. Molina A, Segura A, García-Olmedo F. Lipid transfer proteins (nsLTPs) from barley and maize leaves are potent inhibitors of bacterial and fungal plant pathogens. FEBS Letters. 1993;316:119-22. doi:10.1016/0014-5793(93)81198-9.

44. Jia Z, Gou J, Sun Y, Yuan L, Tang Q, Yang X, et al. Enhanced resistance to fungal pathogens in transgenic Populus tomentosa Carr. by overexpression of an nsLTP-like antimicrobial protein gene from motherwort (Leonurus japonicus). Tree Physiology. 2010;30:1599-605. doi:10.1093/treephys/tpq093.

45. Zhang S, Wang X. One new kind of phytohormonal signaling integrator: Up-and-coming GASA family genes. Plant Signaling \& Behavior. 2017;12:e1226453. doi:10.1080/15592324.2016.1226453.

46. Nahirñak V, Almasia NI, Hopp HE, Vazquez-Rovere C. Snakin/GASA proteins: involvement in hormone crosstalk and redox homeostasis. Plant signaling \& behavior. 2012;7:1004-8. doi:10.4161/psb.20813.

47. Bindschedler L v., Whitelegge JP, Millar DJ, Bolwell GP. A two component chitin-binding protein from French bean - association of a proline-rich protein with a cysteine-rich polypeptide. FEBS Letters. 2006;580:1541-6. doi:10.1016/j.febslet.2006.01.079.

48. Massonnet M, Morales-Cruz A, Figueroa-Balderas R, Lawrence DP, Baumgartner K, Cantu D. Condition-dependent co-regulation of genomic clusters of virulence factors in the grapevine trunk pathogen Neofusicoccum parvum. Molecular Plant Pathology. 2018;19:21-34. doi:10.1111/mpp.12491.

49. Rep M. Small proteins of plant-pathogenic fungi secreted during host colonization. FEMS Microbiology Letters. 2005;253:19-27. doi:10.1016/j.femsle.2005.09.014.

50. Kulkarni RD, Kelkar HS, Dean RA. An eight-cysteine-containing CFEM domain unique to a group of fungal membrane proteins. Trends in Biochemical Sciences. 2003;28:118-21. doi:10.1016/S09680004(03)00025-2.

51. Fass D. Disulfide Bonding in Protein Biophysics. Annual Review of Biophysics. 2012;41:63-79. doi:10.1146/annurev-biophys-050511-102321. 
52. Fass D, Thorpe C. Chemistry and Enzymology of Disulfide Cross-Linking in Proteins. Chemical Reviews. 2018;118:1169-98. doi:10.1021/acs.chemrev.7b00123.

53. Zhu W, Wei W, Wu Y, Zhou Y, Peng F, Zhang S, et al. BcCFEM1, a CFEM Domain-Containing Protein with Putative GPI-Anchored Site, Is Involved in Pathogenicity, Conidial Production, and Stress Tolerance in Botrytis cinerea. Frontiers in Microbiology. 2017;8. doi:10.3389/fmicb.2017.01807.

54. DeZwaan TM, Carroll AM, Valent B, Sweigard JA. Magnaporthe grisea Pth $11 \mathrm{p}$ Is a Novel Plasma Membrane Protein That Mediates Appressorium Differentiation in Response to Inductive Substrate Cues. The Plant Cell. 1999;11:2013-30. doi:10.1105/tpc.11.10.2013.

55. Vaknin Y, Shadkchan Y, Levdansky E, Morozov M, Romano J, Osherov N. The three Aspergillus fumigatus CFEM-domain GPI-anchored proteins (CfmA-C) affect cell-wall stability but do not play a role in fungal virulence. Fungal Genetics and Biology. 2014;63:55-64. doi:10.1016/j.fgb.2013.12.005.

56. Tapia-Tussell R, Lappe P, Ulloa M, Quijano-Ramayo A, Cáceres-Farfán M, Larqué-Saavedra A, et al. A rapid and simple method for DNA extraction from yeasts and fungi isolated from Agave fourcroydes. Molecular biotechnology. 2006;33:67-70.

57. Glass NL, Donaldson GC. Development of primer sets designed for use with the PCR to amplify conserved genes from filamentous ascomycetes. Applied and environmental microbiology. 1995;61:1323-30.

58. Cheng C, Zhao X, Zhang M, Bai F. Absence of Rtt109p, a fungal-specific histone acetyltransferase, results in improved acetic acid tolerance of Saccharomyces cerevisiae. FEMS yeast research. 2016;16:fow010.

59. Sakalidis ML, Ray JD, Lanoiselet V, Hardy GEStJ, Burgess TI. Pathogenic Botryosphaeriaceae associated with Mangifera indica in the Kimberley Region of Western Australia. European Journal of Plant Pathology. 2011;130:379-91. doi:10.1007/s10658-011-9760-z.

60. Slippers B, Crous PW, Denman S, Coutinho TA, Wingfield BD, Wingfield MJ. Combined multiple gene genealogies and phenotypic characters differentiate several species previously identified as Botryosphaeria dothidea. Mycologia. 2004;96:83-101. doi:10.2307/3761991.

61. Daudi A, O'Brien J. Detection of Hydrogen Peroxide by DAB Staining in Arabidopsis Leaves. BIOPROTOCOL. 2012;2. doi:10.21769/BioProtoc. 263.

62. Bozzola JJ, Russell LD. Electron Microscopy: Principles and Techniques for Biologists. Jones and Bartlett; 1999. https://books.google.com.mx/books?id=zMkBAPACbEkC.

63. Emanuelsson O, Brunak S, von Heijne G, Nielsen H. Locating proteins in the cell using TargetP, SignalP and related tools. Nature protocols. 2007;2:953-71. doi:10.1038/nprot.2007.131.

64. Omasits U, Ahrens $\mathrm{CH}$, Müller S, Wollscheid B. Protter: interactive protein feature visualization and integration with experimental proteomic data. Bioinformatics. 2014;30:884-6. doi:10.1093/bioinformatics/btt607.

65. Almagro Armenteros JJ, Tsirigos KD, Sønderby CK, Petersen TN, Winther O, Brunak S, et al. SignalP 5.0 improves signal peptide predictions using deep neural networks. Nature Biotechnology. 
2019;37:420-3. doi:10.1038/s41587-019-0036-z.

66. Almagro Armenteros JJ, Sønderby CK, Sønderby SK, Nielsen H, Winther O. DeepLoc: prediction of protein subcellular localization using deep learning. Bioinformatics. 2017;33:3387-95. doi:10.1093/bioinformatics/btx431.

67. Kulmanov M, Hoehndorf R. DeepGOPlus: improved protein function prediction from sequence. Bioinformatics. 2019. doi:10.1093/bioinformatics/btz595.

68. Kumar S, Stecher G, Li M, Knyaz C, Tamura K. MEGA X: Molecular Evolutionary Genetics Analysis across Computing Platforms. Molecular Biology and Evolution. 2018;35:1547-9. doi:10.1093/molbev/msy096.

69. Jones DT, Taylor WR, Thornton JM. The rapid generation of mutation data matrices from protein sequences. Bioinformatics. 1992;8:275-82. doi:10.1093/bioinformatics/8.3.275.

70. Waterhouse AM, Procter JB, Martin DMA, Clamp M, Barton GJ. Jalview Version 2-a multiple sequence alignment editor and analysis workbench. Bioinformatics. 2009;25:1189-91. doi:10.1093/bioinformatics/btp033.

71. Notredame C, Higgins DG, Heringa J. T-coffee: a novel method for fast and accurate multiple sequence alignment 1 1Edited by J. Thornton. Journal of Molecular Biology. 2000;302:205-17. doi:10.1006/jmbi.2000.4042.

72. Thornton B, Basu C. Real-time PCR (qPCR) primer design using free online software. Biochemistry and Molecular Biology Education. 2011;39:145-54.

73. Pfaffl MW. A new mathematical model for relative quantification in real-time RT-PCR. Nucleic Acids Research. 2001;29:45e-45. doi:10.1093/nar/29.9.e45.

74. Vandesompele J, de Preter K, Pattyn F, Poppe B, van Roy N, de Paepe A, et al. Accurate normalization of real-time quantitative RT-PCR data by geometric averaging of multiple internal control genes. Genome biology. 2002;3:RESEARCH0034. doi:10.1186/gb-2002-3-7-research0034.

\section{Tables}

Due to technical limitations the Tables area available as a download in the Supplementary Files.

\section{Additional File Legend}

Additional file 1 Figure S1. Pathogenicity screening in A. thaliana seedlings. 14-day-old $A$. thaliana seedlings infected with different fungal isolates.

Additional file 2 Figure S2. Molecular identification of the Liqui 1-3 strain.

Additional file 3 Table S1. Primers used in this study for the molecular identification of Liqui 1-3 strain and qRT-PCR experiments.

Additional file 4 Figure S3. Infection of L. styraciflua fresh stems with N. parvum. 
Additional file 5 Figure S4. DAB staining of $L$. styraciflua leaves infected with $N$. parvum at early stages of infection.

Additional file 6 Table S2. CysRP nucleotide sequences.

Additional file 7 Table S3. Disulfide bonds prediction for CysRPs.

Additional file 8 Figure S5. Multiple-sequence alignment of NpCysRPs and other orthologous sequences.

Additional file 9 Figure S6. Predicted proteoforms of NpCysRP2 and other orthologous sequences.

Additional file 10 Figure S7. Multiple-sequence alignment of NpCysRPs and other orthologous sequences.

\section{Figures}

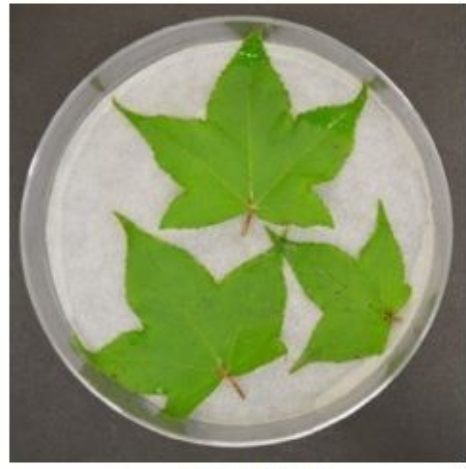

Control

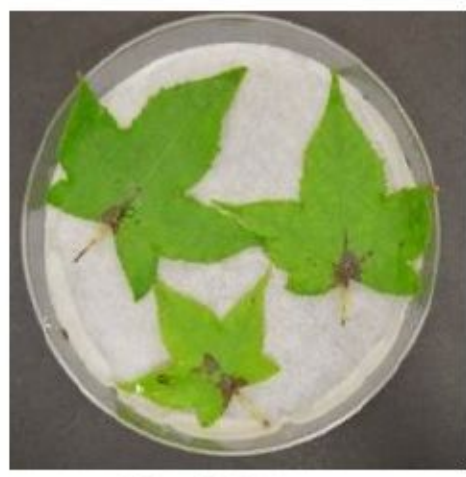

Liqui 2-3

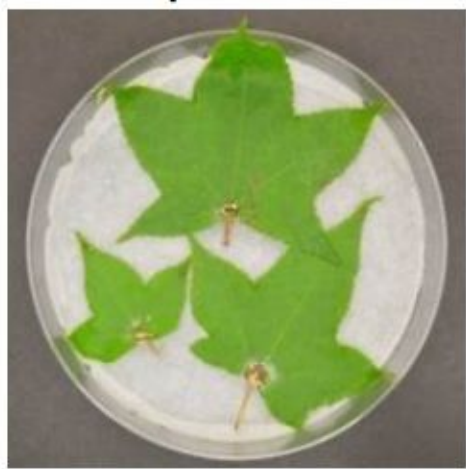

Liqui 1-04

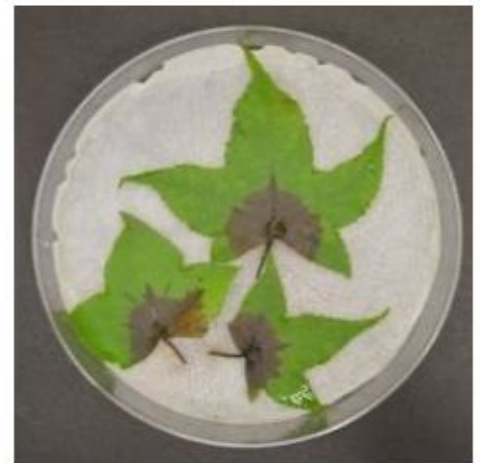

Liqui 1-3

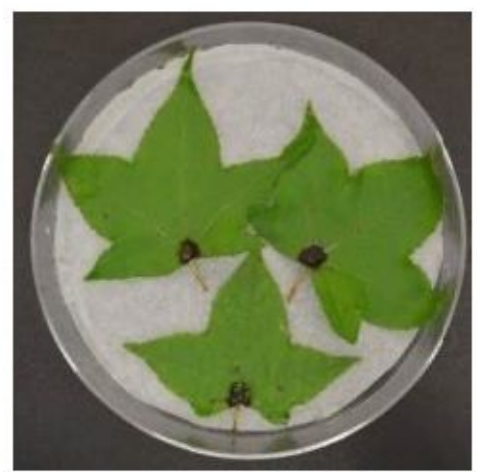

Liqui 1-2-01

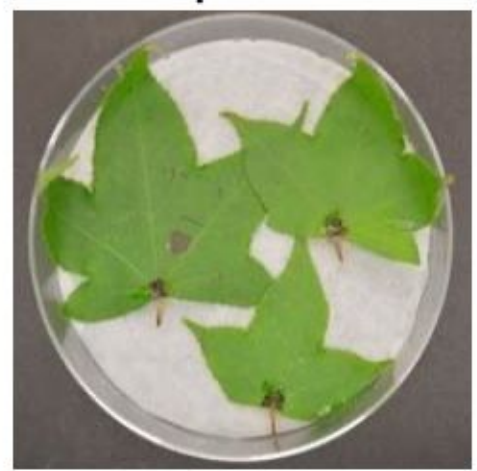

Liqui 1-01

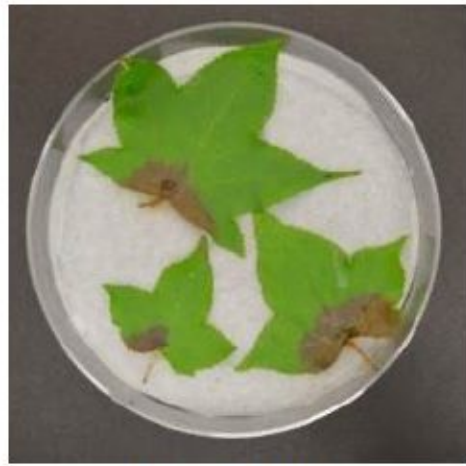

Liqui 1-02

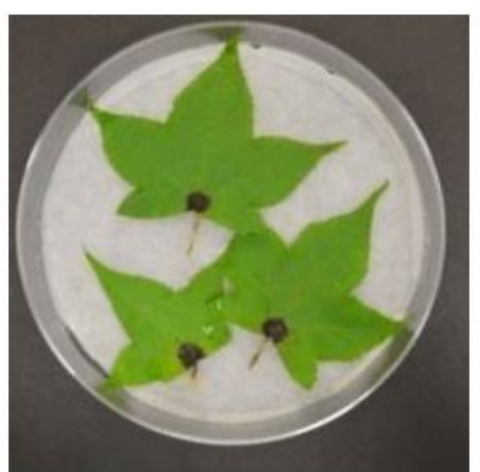

Liqui 1-2-03

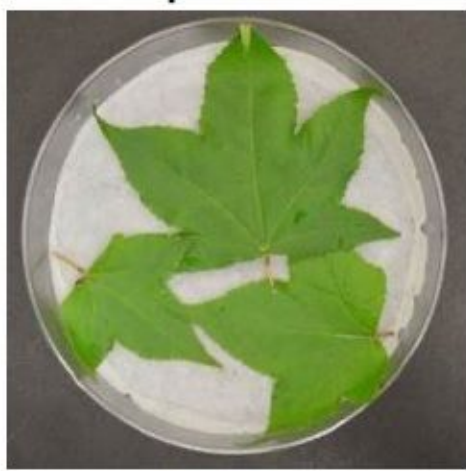

Liqui 3-3

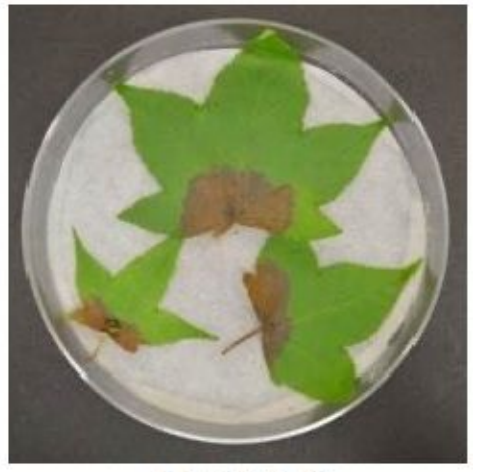

Liqui 2-2

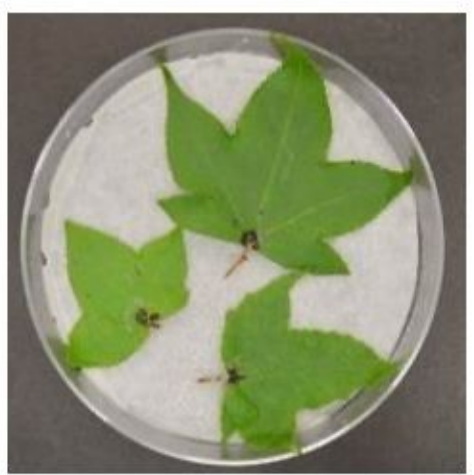

Liqui 3-2

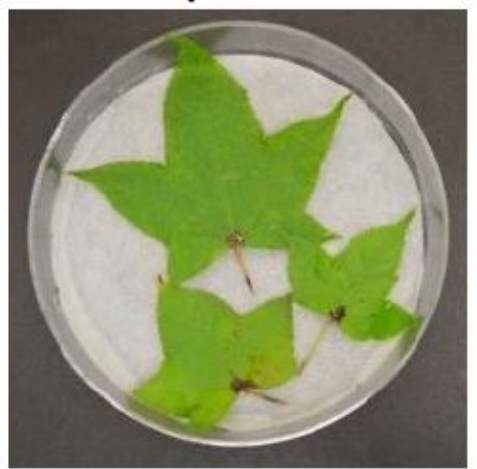

Liqui 3-1 
Figure 1

Pathogenicity screening of the different fungal isolates in L. styraciflua leaves. L. styraciflua leaves were collected from adult trees and infected with different fungal isolates. The photograph was taken at $7 \mathrm{dpi}$. The data are representative of at least three independent experiments.

\section{Control}

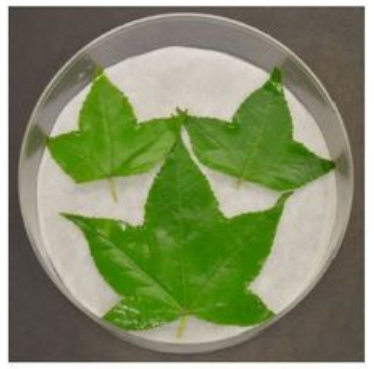

0

+ Neofusicoccum parvum

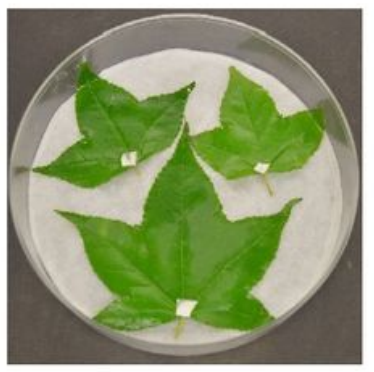

0

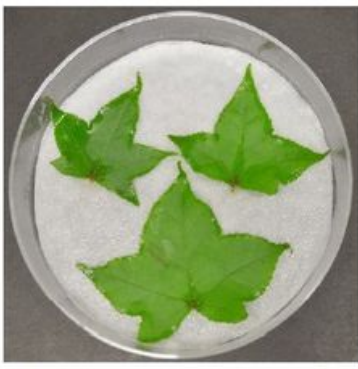

1

3
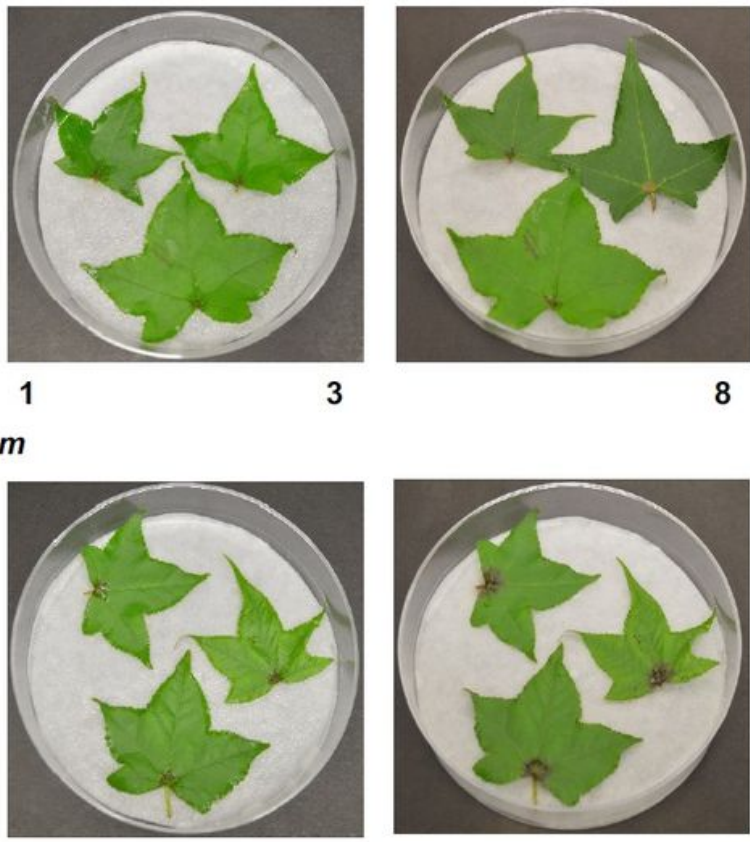

1

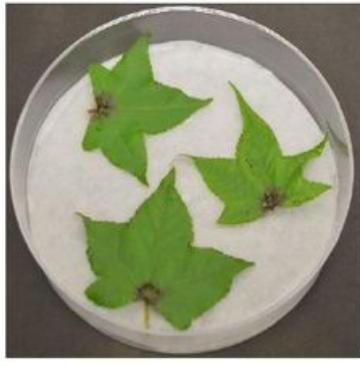

8

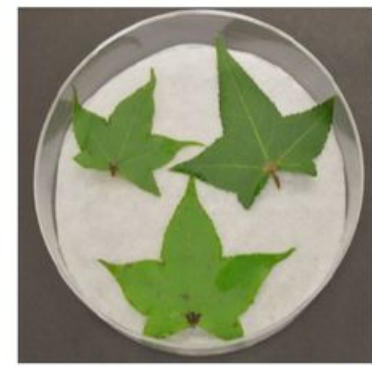

16

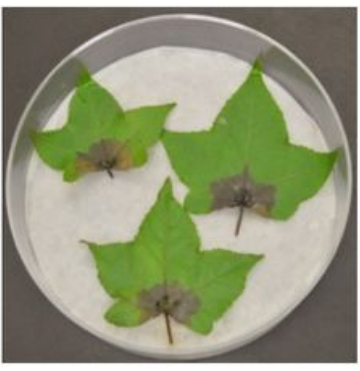

16

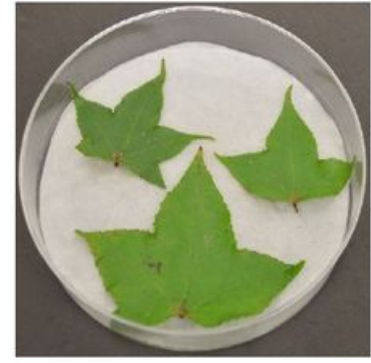

dpi

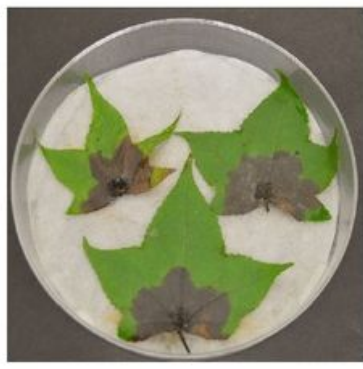

dpi

\section{Figure 2}

The N. parvum and L. styraciflua pathosystem. The leaves collected from adult trees were injured with a scalpel at the base before being inoculated with a PDA plug $(0.5 \mathrm{~cm} \times 0.5 \mathrm{~cm})$ from a 7-day-old culture of the Liqui 1-3 strain. The control leaves were also injured. The photographs were taken at 0, 1, 3, 8 and 16 dpi. Data are representative of at least three independent experiments. 

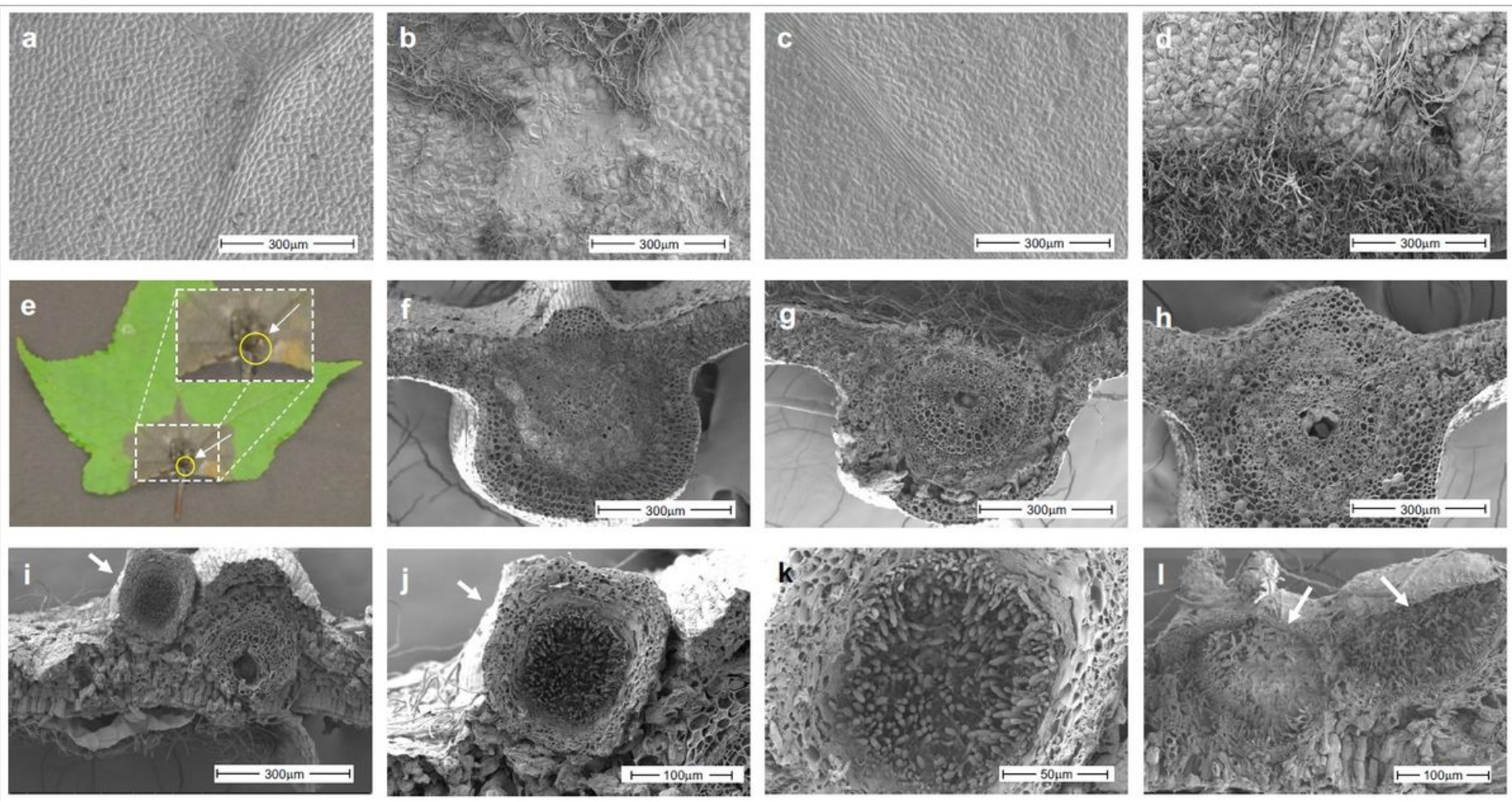

\section{Figure 3}

Analysis by scanning electron microscopy of N. parvum infection in L. styraciflua leaves. a. and c. Control adaxial leaves at 3 and $8 \mathrm{dpi}$, respectively. b. and d. Infected axial leaves at 3 and $8 \mathrm{dpi}$, respectively. e. Leaf base infection; the dashed squares indicate the zones that were analyzed in $\mathrm{f}$ to $\mathrm{l}$. $\mathrm{f}$. and $\mathrm{h}$. Control at 3 and $8 \mathrm{dpi}$, respectively. g. Infected sample at $3 \mathrm{dpi}$. i-I. Infected sample at $8 \mathrm{dpi}$. The arrows indicate the pycnidium and conidia of N. parvum. 
A
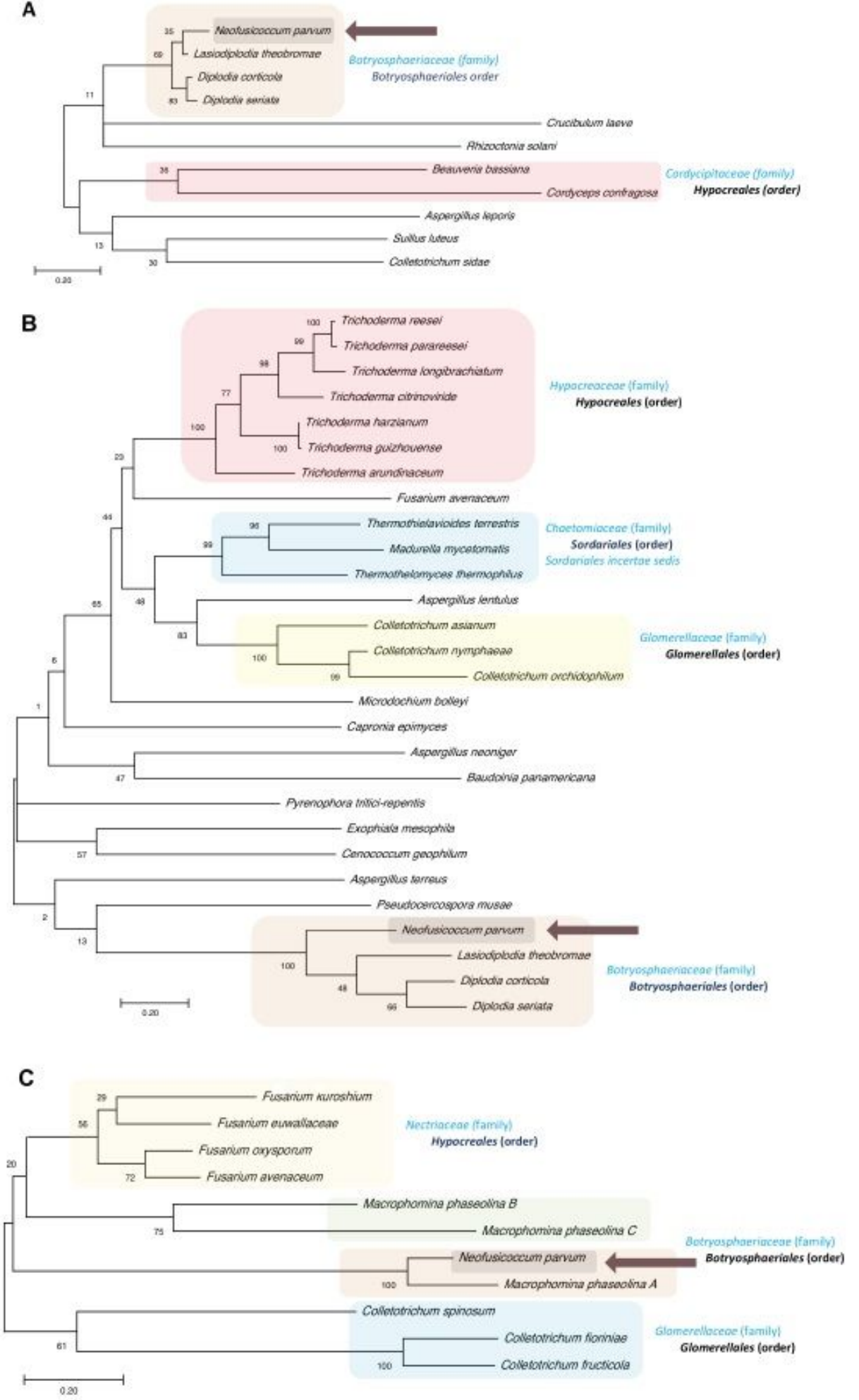

\section{Figure 4}

Phylogenetic analyses of NpCysRP1, NpCysRP2 and NpCysRP3 with orthologs from other fungal species. The phylogenetic trees were constructed using protein sequences with the maximum likelihood method and JTT matrix-based model. NpCysRP1, NpCysRP2 and NpCysRP3 trees with the highest log likelihood values, (-2656.73), (-15145.13) and (-5228.55), respectively, are shown. The percentage of trees in which the associated taxa clustered together is shown next to the branches. The trees are drawn to scale, with 
branch lengths measured in terms of the number of substitutions per site. A. For NpCysRP1, the amino acid sequences are from N. parvum (EOD50423.1), L. theobromae (KAB2569989.1), and D. corticola (XP_020126718.1), D. seriata (KKY27788.1), C. laeve (TFK32468.1), R. solani (CUA75287.1), B. bassiana (PQK10211.1), C. confragosa (OAA70963.1), A. leporis (KAB8069877.1), S. luteus (KIK46160.1), C. sidae (TEA07484.1). B. For NpCysRP2, the amino acid sequences are from T. reesei (XP_006969324.1), T. parareesei (A9Z42_0055550), T. longibrachiatum (PTB72285.1), T. citrinoviride (XP_024746670.1), T. harzianum (XP_024771023.1), T. guizhouense (PB44849.1), T. arundinaceum (RFU76343.1), $F$. avenaceum (KIL85060.1), T. terrestris (XP_003656631.1) M. mycetomatis (KXX77126.1), T. thermophilus (XP_003666291.1), A. lentulus (KKO98531.1), C. asianum (KAF0319766.1), C. nymphaeae (KXH38321.1), C. orchidophilum (XP_022481280.1), M. bolleyi (KXJ94843.1), C. epimyces (XP_007733601.1), A. neoniger (XP_025474954.1), B. panamericana (XP_007680904.1), P. tritici-repentis (XP_001934627.1), E. mesophila (RVX68508.1), A. terreus (XP_001217394.1), P. musae (KXT13283.1), N. parvum (EOD50922.1), L. theobromae (KAB2578904.1), D. corticola (XP_020125849.1) and D. seriata (KKY21900.1). C. For NpCysRP3, the amino acid sequences are from F. kuroshium (RMI89680.1), F. euwallaceae (RTE68176.1), F. oxysporum (EXK86396.1), F. avenaceum (KIL83641.1), M. phaseolina B, (EKG22346.1), M. phaseolina C (EKG22347.1), N. parvum (EOD52838.1), M. phaseolina A (EKG20686.1), C. spinosum (TDZ33147), C. fioriniae (EXF77634.1), C. fructicola (XP_031888108).
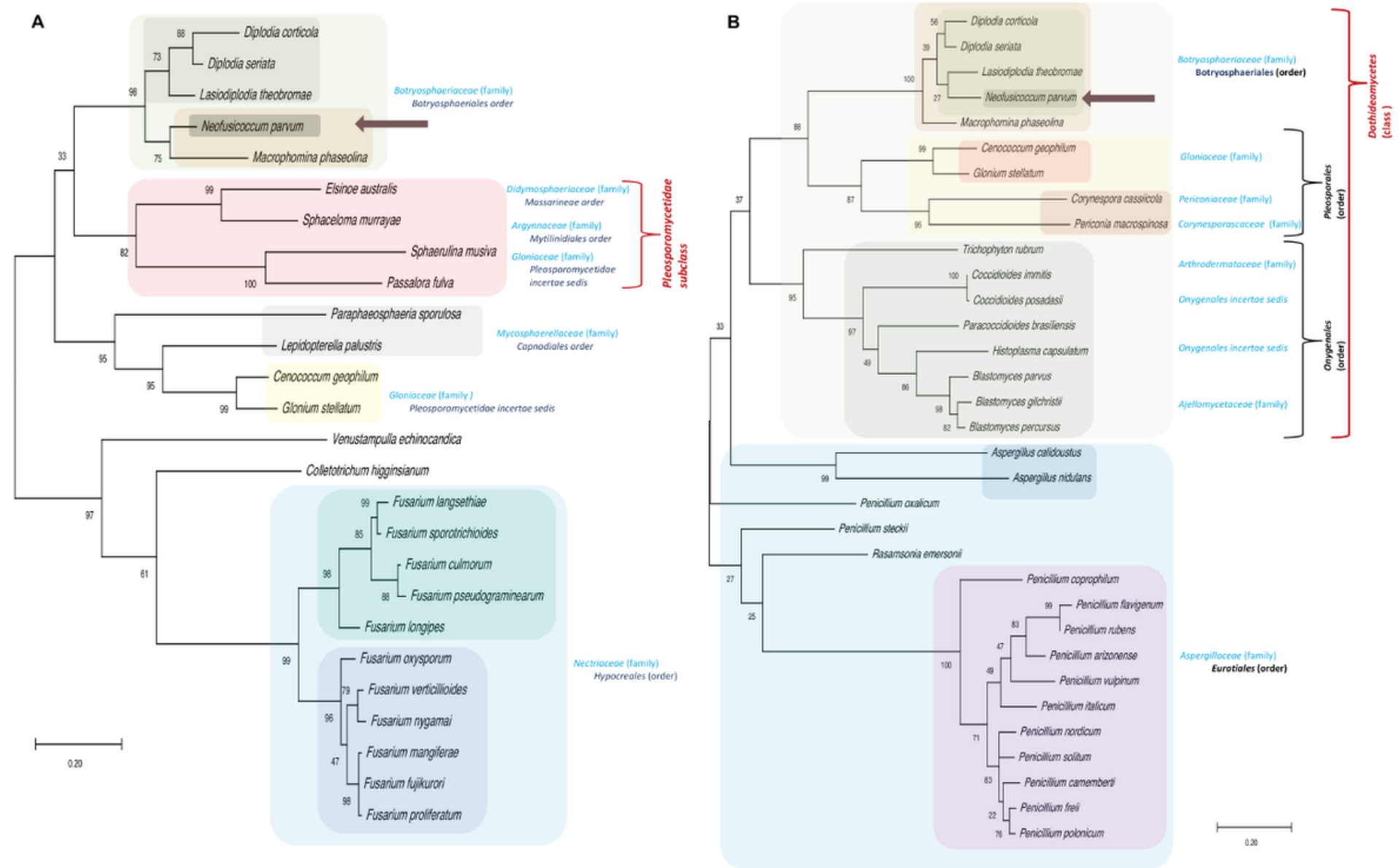

Figure 5 
Phylogenetic analyses of NpCysRP4 and NpCysRP5 with orthologs from other fungal species. The phylogenetic trees were constructed using protein sequences with the maximum likelihood method and JTT matrix-based model. NpCysRP4 and NpCysRP5 trees with the highest log likelihood values, $(-4619.05)$ and (-6976.31), respectively, are shown. The percentage of trees in which the associated taxa clustered together is shown next to the branches. The trees are drawn to scale, with branch lengths measured in terms of the number of substitutions per site. A. For NpCysRP4, the amino acid sequences are from D. corticola (XP_020129061.1), D. seriata (KKY13873.1), L. theobromae (KAB2571564.1), N. parvum (EOD51105.1), M. phaseolina (EKG14570.1), E. australis (TKX25331.1), S. murrayae (PNS17704.1), S. musiva (XP_016758053.1), P. fulva (AQA29231.1), P. sporulosa (XP_018029092.1), L. palustris (OCK84136.1), C. geophilum (OCK98732.1), G. stellatum (OCL13334.1), V, echinocandica (RDL36609.1), C. higginsianum (TIC93879.1) F. langsethiae (KPA46759.1), F. sporotrichioides (RGP70600.1), F. culmorum (PTD11477.1), F. pseudograminearum (XP_009256009.1), F. longipes (RGP60032.1), F. oxysporum (EXA53032.1), F. verticillioides (RBR06989.1), F. nygamai (PNP52701.1), F. mangiferae (CVK83605.1), F. fujikurori (QGI58805.1), F. proliferatum (XP_031075444.1). B. For NpCysRP5, the amino acid sequences are from D. corticola (XP_020133845.1), D. seriata (KKY24076.1), L. theobromae (KAB2577423.1), N. parvum (EOD44996.1), M. phaseolina (EKG19367.1), C. geophilum (OCK97775.1), G. stellatum (OCL07361.1), C. cassiicola (PSN73263.1), P. macrospinosa (PVI08476.1), Trichophyton rubrum (XP_003231199.1), C. immitis (XP_001240075.1), C. posadasii (XP_003069153.1), P.s brasiliensis (ODH22777.1), H. capsulatum (EEH05575.1), Bl. parvus (OJD22636.1), A. calidoustus (CEL09455.1), A. nidulans (XP_660049.1), P. oxalicum (EPS32950.1), P. steckii (OQE27319.1), Rasamsonia emersonii (XP_013330685.1) P. coprophilum (OQE36870.1) P. flavigenum (OQE32686.1), P. rubens (XP_002567673.1), P. arizonense (XP_022485186.1), P. vulpinum (OQE12392.1), P. italicum (KG074509.1), P. nordicum (KOS37798.1), P. solitum (OQD85155.1), P. camemberti (CRL28928.1), P. freii (KUM58798.1), P. polonicum (OQD69393.1). 

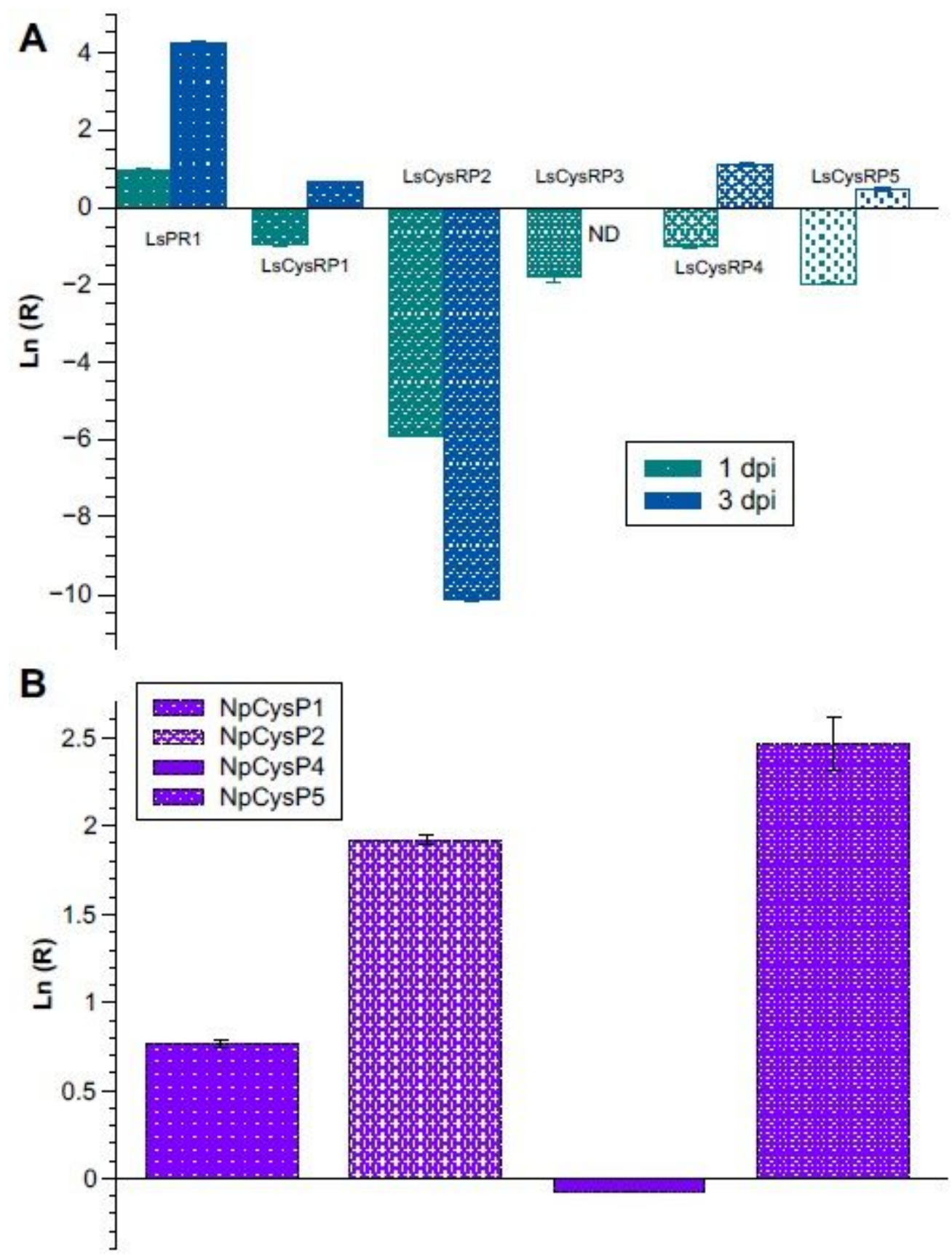

Figure 6

Expression at early stages of infection of CysRP mRNAs of both L. styraciflua and N. parvum. A. LsCysRP mRNA expression at 1 and $3 \mathrm{dpi}$. For the analysis, the geometric mean between Tip41 and actin was used as a reference. For all the transcript statistics, significant differences were detected between 1 and $3 \mathrm{dpi}$ at $\mathrm{P}<0.01$ using Student's t test. B. NpCysRP mRNA expression from 1 to $3 \mathrm{dpi}$. NpCysRP3 was used as a reference gene. Data are the average of three independent inoculation experiments.

\section{Supplementary Files}

This is a list of supplementary files associated with this preprint. Click to download. 
- Additionalfile3.pdf

- Additionalfile7.pdf

- Additionalfile6.pdf

- Additionalfile4.pdf

- Additionalfile2.pdf

- Additionalfile8.pdf

- Additionalfile5.pdf

- Additionalfile10.pdf

- Additionalfile1.pdf

- Additionalfile9.pdf

- Formula.pdf

- Tables.pdf 